\title{
HUBUNGAN PENGORGANISASIAN PROGRAM TERHADAP KINERJA PAMONG BELAJAR PADA SANGGAR KEGIATAN BELAJAR
}

\author{
Harol R. Lumapow \\ Universitas Negeri Manado (e-mail: hlumapow_unima@gmail.com; \\ HP: 081340713351)
}

\begin{abstract}
The Relationship between the Program Organization and the Learning Tutors' Performance in Learning Activity Workshops. This study aims to investigate the functional relationship between learning tutors' motivation, supervision intensity, program organization, and learning tutors' work performance. This study was a survey using a correlational method. The sample, consisting of 63 learning tutors, was randomly selected. The results show that there is a positive correlation between: (1) program organization and learning tutors' work performance of with $r$ $=0.84$; (2) work motivation and learning tutors' work performance of with $\mathrm{r}=0.77$; and (3) supervision intensity and learning tutors' work performance of with $r=$ 0.68 . The regression equation is $\hat{Y}=0,58 X_{1}+0,47 X_{2}+0.42 X_{3}-29.73$.
\end{abstract}

Keywords: program organization, work motivation, supervision intensity, learning tutors' work performance

\section{PENDAHULUAN}

Manusia sebagai subjek pembangunan memerlukan kemampuan profesional dan ditopang dengan jumlah tenaga yang memadai. Tanpa demikian, maka tidak akan memungkinkan suatu negara dapat berinovasi untuk mencapai perubahan dan peradaban yang maju. Berbagairealita menunjukkan bahwa bagi negara-negara yang dikategorikan maju ternyata dipengaruhi oleh begitu memadainya sumber daya manusia, baik kualitas maupun kuantitas. Hal ini mengisyaratkan bahwa semakin tinggi kualitas dan kuantitas sumber daya manusia suatu bangsa, semakin berpeluang untuk mencapai kemajuan pembangunan.

Untuk mendapatkan sumber daya manusia professional, diperlukan pendi- dikan yang memadai yang ditopang oleh manajeman yang profesional. Pendidikan merupakan salah satu sub sistem pembangunan yang sangat strategis bagi tercapainya tujuan pembangunan. Undang-Undang No.20Tahun 2003 tentang Sistem Pendidikan Nasional pasal 13 ayat 1 menyatakan bahwa jalur pendidikan terdiri atas pendidikan formal, nonformal, dan informal. Pendidikan formal adalah jalur pendidikan yang terstruktur dan berjenjang yang terdiri atas pendidikan dasar, pendidikan menengah, dan pendidikan tinggi. Pendidikan nonformal adalah jalur pendidikan di luar pendidikan formal yang dapat dilaksanakan secara terstruktur dan berjenjang. Pendidikan informal adalah jalur pendidikan keluarga dan lingkungan. Tiga jalur pendidikan seperti yang 
telah diuraikan di atas, memiliki kedudukan dan peran yang sama untuk mencapai tujuan pembangunan nasional.

Pendidikan nonformal merupakan salah satu jalur pendidikan yang memberikan pelayanan kepada masyarakat yang tidak didapatkannya melalui jalur pendidikan formal. Di samping itu, dapat memberikan pelayanan dalam rangka menambah dan melengkapi yang telah diperolehnya melalui jalur pendidikan formal. Dalam Undang-Undang Sisdiknas Nomor 20 Tahun 2003 pasal 1 ditegaskan bahwa pendidikan nonformal diselenggarakan bagi warga masyarakatyang memerlukan layanan pendidikan yang berfungsi sebagai pengganti, penambah, dan/atau pelengkap pendidikan formal dalam rangka mendukung pendidikan sepanjang hayat. Melalui pendidikan nonformal, diharapkan semua anggota masyarakat yang memerlukan pelayanan pendidikan akan terlayani.

Depdiknas (1999) mengemukakan bahwa pamong belajar adalah pegawai negeri sipil (PNS) yang diberi tugas, tanggung jawab, wewenang, dan hak secara penuh oleh pejabat yang berwenang untuk melaksanakan kegiatan belajar mengajar dalam rangka pengembangan model dan pembuatan percontohan serta penilaian dalam rangka pengendalian mutu dan dampak pelaksanaan program pendidikan luar sekolah, pemuda dan olahraga. Selanjutnya, Depdiknas (2009) mengemukakan bahwa pamong belajar merupakan salah satu komponen penting dan strategis bagi tercapainya tujuan SKB. Pamong belajar berfungsi sebagai pengelola program pendidikan yang dibutuhkan oleh war- ga belajar dan sekaligus dapat bertindak sebagai pendidik yang melakukan proses pembelajaran.

Berdasarkan uraiandi atas, maka pamongbelajar adalah sebagai tenaga pendidik non formal merupakan salah satu komponen yang penting dan strategis dalam SKB yang berfungsi sebagai perencana, pelaksana dan evaluasi program pendidikan. Fungsi pamong belajar sebagai perencana diwujudkan melalui segenap akivitas dalam bentuk perencanaan proses pembelajaran, pelaksanaan proses pembelajaran serta mengevaluasi hasil proses pembelajaran. Fungsi evaluasi diwujudkan melalui penilaian terhadap hasil segenap program pendidikan yang telah dilaksanakan, apakah telah berjalan sesuai dengan yang direncanakan. Darifungsi tersebut menunjukkan bahwa peran pamong belajar bukan hanya pada tatanan manajer program pembelajaran, melainkan lebih dari itu yaitu menjadi manajer program pendidikan. Hal inilah yang membedakan antara peran guru dan pamong belajar. Fungsi pamong belajar pada umumnya menjadi fungsi sanggar kegiatan belajar sehingga dalam pembentukannya perlu pamong belajar.

Berbagai fakta di lapangan menunjukkan bahwa banyak pamong belajar kurang optimal melakukan tugas, sementara begitu banyak program belajar yang dapat dilakukan untuk masyarakat. Selain itu, masih banyak pamong belajar yang melakukan tugas berorientasi pada aktivitas administrasi, tidak diselesaikan secara tuntas, banyak program belajar berjalan tidak sesuai dengan apa yang direncanakan, bekerja menunggu program dari atas, bekerja 
atas prinsip rutinitas, dan kurang melakukan kunjungan di lapangan dan sebagainya.

Whitmore (1997) mengartikan kinerja sebagai "suatu perbuatan, suatu prestasi, atau suatu pemeran umum keterampilannya. Suprihanto (1998) mengemukakan bahwa kinerja seorang tenaga kerja adalah hasil kerja seorang tenaga kerja selama periode tertentu dibandingkan dengan berbagai kemungkinan yang telah ditentukan dahulu dan telah disepakati bersama. Sedarmyati (1996) mengemukakan bahwa kinerja individu dapat dinilai dari apa yang dilakukan individu tersebut dalam kerjanya. Dengan kata lain, kinerja individu adalah bagaimana seseorang melaksanakan pekerjaannya atau unjuk kerja. Simamora mengemukakan bahwa kinerja mengacu pada kadar pencapaian tugas-tugas yang membentuk sebuah pekerjaan karyawan.

Berdasarkan uraian di atas, dapat disimpulkan bahwa kinerja merupakan komponenintiyang dapat dijadikan landasan penilaian bagi pamong belajar dalam penyelenggaraan program pendidikan nonformal pada SKB. Dalam arti bahwa ukuran seorang pamong belajar telah melakukan fungsinya akan tergambar melalui kinerjanya.

Pengorganisasian merupakan salah satu fungsi manajemen dan dalam pengertiannya terdapat perbedaan pandangan antara satu ahli dengan ahli lainnya. Hal ini dikarenakan kondisi lingkungan dalam penerapannya. Menurut Longenecher (1973), pengorganisasian sebagai aktivitas menetapkan hubungan antara manusia dan kegiatan yang dilakukan untuk mencapai tujuan.
Connor, dkk. (1973) memberikan arti pengorganisasian sebagai aktivitas melayani proses kegiatan untuk mencapai tujuan yang telah ditetapkan. Flippo dan Musinger (1975) mengartikan pengorganisasian sebagai kegiatan merancang dan menetapkan komponen pelaksanaan suatu proses kegiatan. Sutestri (2008) mengemukakan bahwa proses pengorganisasian kerja melalui tahapan-tahapan, seperti: (1) perincian pekerjaan atau deskripsi tugas; (2) pembagian tugas; (3) pemisahan pekerjaan dan penempatan; (4) koordinasi pekerjaan; dan (5) pengawasan.

Berdasarkan beberapa pengertian pengorganisasian sebagaimana yang telah dikemukakan di atas, dapat disimpulkan bahwa pengorganisasian program adalah usaha mengintegrasikan sumber daya manusia dan nonmanusia ke dalam suatu kesatuan pelaksanaan kegiatan dalam mencapai tujuan yang telah ditetapkan. Hal ini menunjukkan bahwa pengorganisasian merupakan proses manajemen dalam rangka membentuk organisasi untuk merealisasikan berbagai rencana guna mencapai tujuan.

Baedhowi (2007) mengutip beberapa pendapat berkaitan dengan motivasi dalam dunia kerja seperti yang dikemukakan Maslow bahwa dunia kerja memiliki motivasi fisiologis, keamanan, rasa memiliki, penghargaan, dan aktualisasi diri. Dalam teori ERG yang dicetuskan Aldefer, dikatakan bahwa dunia kerja memiliki motivasi keberadaan, keterkaitan, dan pertumbuhan. Menurut Mclelland, dunia kerja memiliki motivasi yang berhubungan dengan keinginan untuk memperoleh pencapaian, keingin- 
an untuk terikat dengan organisasi tertentu, dan keinginan memperoleh kekuasaan.

Berdasarkan berbagai pendapat di atas, dapat disimpulkan bahwa motivasi kerja adalah segenap daya atau kekuatan, baik dari dalam maupun dari luar yang menggerakkan seseorang untuk melakukan suatu pekerjaan yang dilimpahkan kepadanya. Motivasi merupakan daya atau kekuatan yang berubah menjadi energi untuk melakukan sesuatu pekerjaan demi tercapainya tujuan. Seseorang termotivasi melakukan pekerjaan karena ada suatu kebutuhan yang ingin dipenuhi.

Untuk mengetahui apakah pamong belajar telah melakukan merencanakan, melaksanakan dan mengevaluasi program pendidikan sesuai dengan program yang ada, maka tugas pimpinan adalah melakukan supervisi. Melalui kegiatan supervise ini, pimpinan dapat memberikan bantuan kepada pamong belajar sehingga mereka dapat melaksanakan tugas berdasarkan program yang ada di SKB. Supervisi adalah serangkaian usaha bantuan kepada pendidik, terutama bantuan yang berwujud profesional yang dilakukan oleh pimpinan, penilik atau pengawas untuk meningkatkan proses dan hasil belajar. Jones (Pidarta, 1988) mengemukakan bahwa supervisi merupakan bagian yang tidak dapat dipisahkan dari seluruh proses administrasi pendidikan yang ditujukan, terutama untuk mengembangkan efektivitas kinerja personalia sekolah yang berhubungan dengan tugas-tugas pendidikan.

Berdasarkan uraian di atas, dapat disimpulkan bahwa supervisi merupa- kan bantuan yang bersifat profesional oleh seorang yang disebut pimpinan kepada pendidik dengan tujuan agar dapat meningkatkan kualitas, proses dan hasil belajar sesuai dengan tujuan pendidikan yang telah direncanakan. Supervisi sebagai suatu kegiatan yang sistematik dan berkelanjutan dalam rangka memotivasi dan memberikan arahan pada pendidik untuk mengembangkan kemampuan yang ada padanya sehingga dapat memberikan kontribusi yang efektif bagi tercapainya tujuan pendidikan.

Sanggar Kegiatan Belajar (SKB) yang berkedudukan di kabupaten/kota merupakan salah satu wadah pendidikan nonformal untuk memberikan pelayanan pendidikan kepada masyarakat yang membutuhkannya. Melalui SKB, diharapkan dapat berperan sebagai wadah untuk memenuhi segenap kebutuhan pendidikan yang tidak didapatkan oleh masyaeakat pada pendidikan formal, apakah dalam posisi menambah, melengkapi, atau mengganti. SKB yang ada di kabupaten/kota di Propinsi Sulawesi Utara menyelenggarakan berbagai program pendidikan, seperti: kelompok belajar paket A, B dan C: pendidikan keterampilan, pendidikan keselarasan, dan pendidikan anak usia dini.

SKB sebagai lembaga pendidikan nonformal diharapkan dapat menjalankan fungsinya untuk menjadi lembaga pendidikan yang profesional. Melalui pelayanan pendidikan yang profesional, akan memungkinkan wadah ini diminati oleh seluruh anggota masyarakat tanpa memperhatikan status sosial ekonomi. Untuk itu, hal ini dapat terwujud apabila semua komponen yang ada di 
dalamnya, terutama sumber daya manusia sebagai motor organisasi dapat berperan secara profesional dalam membangun visi dan misi pendidikan. Sebagai lembaga pendidikan formal, diharapkan nilai-nilai pendidikan akan selalu menjadi pedoman dasar bagi penyelenggara dalam melaksanakan tugas lembaga.

Secara kuantitatif, SKB dipandang berhasil apabila mampu menghasilkan jumlah lulusan yang seimbang antara input dan out put. Dalam arti, semua peserta didik tidak ada yang mengalami drop out selama program pendidikan berjalan. Secara kualitatif, diharapkan segenap hasil yang diproses melalui wadah ini memiliki kualitas memadai. Artinya, mereka yang diproses bukan hanya sekedar lulus untuk memenuhi target kuantitatif, melainkan lulusan yang ada memiliki segenap pengetahuan, sikap, dan ketrampilan sebagaimana yang mereka butuhkan dan dapat diaplikasikan dalam kehidupan nyata.

Realita di lapangan menunjukkan bahwa SKB sebagai wadah pembelajaran masyarakat belum menunjukkan hasil yang optimal. Masih banyak anggota masyarakat yang tidak terlayani melalui pendidikan formal, belum terlayani kebutuhan belajarnya pada SKB. Hal ini telihat dengan masih banyak peserta didik pada SKB kurang terampil setelah mengikuti pendidikan. Selain itu, banyak program di SKB yang kurang relevan dengan kebutuhan masyarakat. Pada umumnya, program yang dilaksanakan merupakan adopsi di tempat lain tanpa memperhatikan situasi dan kondisi setempat, dan sebagainya.
Penelitian ini difokuskan pada faktor eksternal, yakni aspek pemimpin dalam hal intensitas supervisi, sedangkan faktor internal dibatasi pada aspek pengorganisasian program dan motivasi kerja. Keempat variabel penelitian sebagaimana yang telah dikemukakan di atas dilakukan pada seluruh kegiatan SKB yang ada Kabupaten/Kota Propinsi Sulawesi Utara.

\section{METODE}

Penelitian ini merupakan penelitian korelasional, yaitu untuk mengetahui hubungan suatu variabel dengan variabel-variabel yang lain. Hubungan antara satu dengan beberapa variabel lain dinyatakan dengan besarnya koefisien korelasi dan kebermaknaan (signifikansi) secara statistik. Adanya korelasi antara dua variabel atau lebih, tidak berarti adanya pengaruh atau hubungan sebab akibat dari suatu variabel terhadap variabel lainnya. Korelasi positif berarti nilai yang tinggi dalam suatu variabel, berhubungan dengannilai yang tinggi dalam variabel lainnya. Korelasi negative berarti nilai yang tinggi dalam suatu variabel berhubungan dengan nilai yang rendah pada variabel lain (Sukmadinata, 2009)

Tujuan penelitian ini adalah untuk mengetahui apakah terdapat hubungan antara variabel bebas $(X)$ dan variabel terikat (Y), seperti berikut.

- Apakah terdapat hubungan antara pengorganisasian program dengan kinerja pamong belajar?

- Apakah terdapat hubungan antara motivasi kerja dengan kinerja pamong belajar? 
- Apakah terdapat hubungan antara intensitas supervisi pendidikan dengan kinerja pamong belajar?

- Apakah terdapat hubungan antara pengorganisasian program, motivasi kerja, dan intensitas supervisi pimpinan secara bersama-sama dengan kinerja pamong belajar?

Berdasarkan tujuan penelitian di atas, metode penelitian yang digunakan dalam penelitian ini adalah penelitian survei dengan pendekatan korelasional.
Subjek penelitian adalah pamong belajar dari masing-masing SKB di Kabupaten/Kota Propinsi Sulawesi Utara. Pengambilan subjek penelitian dengan menggunakan teknik proportional random sampling dalam arti bahwa sebelum dilakukan penarikan sampel secara random, terlebih dahulu menetapkan proporsi dari masing-masing SKB. Hal ini dilakukan agar masing-masing SKB terwakili. Ukuran sampel yang ditetapkan dalam penelitian ini sebanyak 63 orang.

Tabel 1. Populasi Pamong Belajar Menurut Tingkat Pendidikan

\begin{tabular}{llccc}
\hline No. & \multicolumn{1}{c}{ Kabupaten/Kota } & $\begin{array}{c}\text { Tingkat } \\
\text { Pendidikan } \\
\text { Terakhir Sarjana }\end{array}$ & $\begin{array}{c}\text { Tingkat } \\
\text { Pendidikan } \\
\text { Teakhir D2 }\end{array}$ & Jumlah \\
\hline 1. & BolaangMongondow & 8 & 2 & 10 \\
2. & BolaangMongondow Utara & 21 & 2 & 23 \\
3. & Minahasa & 37 & 8 & 45 \\
4. & Tomohon & 6 & 2 & 8 \\
5. & Minahasa Utara & 5 & 2 & 7 \\
6. & Bitung & 8 & 2 & 10 \\
7. & Sangihe & 8 & 2 & 10 \\
8. & Talaud & 4 & 4 & 8 \\
9. & Minahasa Selatan & 5 & 2 & 7 \\
& Jumlah & 102 & 26 & 128 \\
\hline
\end{tabular}

Untuk menentukan besarnya sampel yang akan ditelit digunakan rumus yang diajukan oleh Tuckman (1972) sebagai berikut.

$$
\mathrm{N}=(\mathrm{z} / \mathrm{e})^{2}(\mathrm{P})(1-\mathrm{P})
$$

\section{Keterangan:}

$\mathrm{n}$ : jumlah sampel minimal

$\mathrm{z}$ : nilai baku dari tabel normal $\mathrm{z}$ dalam selang kepercayaan tertentu

e : kekeliruan sampling yang ditolerir

$\mathrm{P}$ : proporsi

Berdasarkan data seperti nampak dalam Tabel 1, didapat proporsi tingkat pendidikan terakhir pamong belajar sebesar 0,80 . Nilai z dalam selang kepercayaan tertentu sebesar 1,96 dan taraf kekeliruan yang ditolerir sebesar 0,10. Dengan demikian, jumlah sampel yang diperlukan dapat dihitung:

$$
\begin{aligned}
\mathrm{n} & =(\mathrm{z} / \mathrm{e}) 2(\mathrm{P})(1-\mathrm{P}) \\
& =1,96 / 0,10^{2}(0,80)(1-0,80) \\
& =384,16 \times(0,80)(0,20) \\
& =384,16 \times 0,16 \\
& =61,47
\end{aligned}
$$

Pengalokasian sampel menurut tingkat pendidikan terakhir pamong belajar dilakukan secara proporsional, sedangkan pemilihan responden untuk setiap tingkat pendidikan, ditentukan dengan menggunakan bilangan random. Ada pun penyebaran pamong belajar sesuai 
tingkat pendidikan yang dijadikan sam- pel sebagai berikut.

Tabel 2. Penyebaran Sampel menurut Tingkat Pendidikan

\begin{tabular}{llccc}
\hline No. & \multicolumn{1}{c}{ Kabupaten/Kota } & $\begin{array}{c}\text { Tingkat } \\
\text { Pendidikan } \\
\text { Terakhir Sarjana }\end{array}$ & $\begin{array}{c}\text { Tingkat } \\
\text { Pendidikan } \\
\text { Teakhir D2 }\end{array}$ & Jumlah \\
\hline 1. & BolaangMongondow & 2 & 2 & 3 \\
2. & BolaangMongondow Utara & 12 & 2 & 14 \\
3. & Minahasa & 20 & 3 & 23 \\
4. & Tomohon & 3 & 1 & 4 \\
5. & Minahasa Utara & 2 & 1 & 3 \\
6. & Bitung & 4 & 1 & 5 \\
7. & Sangihe & 4 & 1 & 5 \\
8. & Talaud & 2 & 1 & 3 \\
9. & Minahasa Selatan & 2 & 1 & 3 \\
& Jumlah & 51 & 12 & 63 \\
\hline
\end{tabular}

Teknik pengumpulan data yang digunakan dalam penelitian ini adalah angket dengan menggunakan skala 1 sampai 5 untuk menggali data tentang pengorganisasian program, motivasi kerja, intensitas supervisi dan kinerja pamong belajar.

Teknik analisis data yang digunakan dalam penelitian ini adalah analisis deskriptif, korelasi, regresi sederhana dan regresi ganda. Hubungan antarvariabel dapat diihat pada gambar berikut ini.

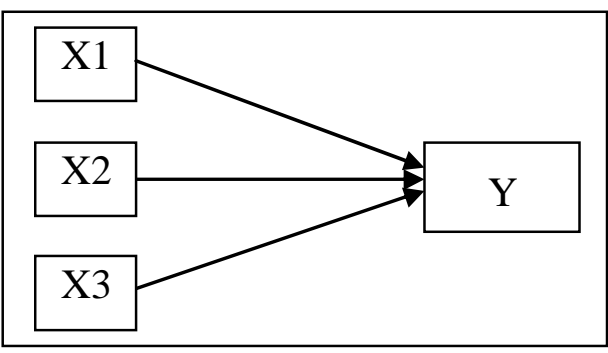

Gambar 1. Hubungan antara Variabel

Bebas (X) dan Variabel Terikat (Y)

Keterangan:

$\mathrm{X} 1$ : Variabel pengorganisasian program
$\mathrm{X} 2$ : Variabel motivasi kerja

$X 3$ : Variabel intensitas pimpinan

$Y$ : Variabel kinerja pamong belajar

\section{Kerangka Pikir}

Pengorganisasian program sebagai kegiatan menyusun dan membentuk hubungan kerja antarindividu sehingga terwujud kesatuan usaha untuk mencapai tujuan yang telah ditetapkan merupakan salah satu fungsi manajemen yang harus dikuasai oleh pamong belajar. Pengorganisasian program yang efektif memungkinkan terciptanya penyelenggaraan program pembelajaran sebagaimana tujuan yang telah ditetapkan.Pengorganisasian program akanmemungkinkan teridentifikasi dan terberdayanya segenap komponen yang dibutuhkan dalam penyelenggaraan program.

Di samping itu, akan memungkinkan terjadinya pembagian tugas, wewenang dan tanggung jawab dari masing-masing sumberdaya yang dibutuhkan. Pengorganisasian program akan 
memungkinkan terciptanya hubungan kerja yang harmonis dan lancar dari segenap sub sistem untuk mencapai tujuan yang telah ditetapkan. Pengorganisasian program yang efektif akan menjadi salah satu modal bagi pamong belajar untuk meningkatkan kinerja. Program pembelajaran yang terorganisasi dengan baik akan membangkitkan semangat kinerja pamong belajar untuk melakukan tugas pembelajaran bagi warganya.

Motivasi merupakan daya atau kekuatan yang menggerakkan seseorang untuk melakukan sesuatu sebagaimana yang ia dambakan. Motivasi erat kaitannya dengan kebutuhan, dalam arti bahwa seseorang bergerak melakukan sesuatu karena ingin memenuhi suatu kebutuhan. Motivasi adalah suatu kekuatan, baik dari dari dalam maupun dari luar yang membuat seseorang untuk bertindak. Seseorang akan melakukan suatu tindakan dilandasi oleh serangkaian kebutuhan yang harus dipenuhi serta tujuan yang hendak dicapai. Motivasi, kebutuhan dan tujuan merupakan tiga komponen yang tidak dapat dipisahkan antara satu denan lainnya.

Motivasi kerja adalah suatu kekuatan, bak dari dalam maupun dari luar yang menggerakkan seseorang untuk melakukan pekerjaan secara optimal sehingga tujuan yang ditetapkan dapat tercapai. Motivasi kerja yang tinggi akan memungkinkan seseorang menampilkan pekerjaan yang tinggi. Dari uraian ini dapat disimpulkan bahwa semakin tinggi motivasi kerja pamong belajar, maka akan semakin tinggi kinerja dalam pelaksanaan tugas dan tanggung jawab yang dipercayakan.
Konsep supervisi didasarkan pada pandangan bahwa pada diri setiap individu terdapat potensi atau kemampuan untuk berkembang. Untuk mengembangkan potensi yang dimiliki oleh setiap individu diperlukan bantuan dari luar sehingga memungkinkan potensi individu dapat berkembang. Hal ini memungkinkan terjadi apabla antara supervisor dan yang di supervisi dapat menciptakan suatu hubungan yang harmonis, yaitu saling keterbukaan dan adanya partisipasi antara satu dengan yang lain. Melalui keterbukaan dan partisipasi sangat memungkinkan dikembangkannya potensi-potensi yang ada dalam diri tiap individu, baik secara pribadi maupun secara bersama-sama.

Supervisi yang dilakukan di Sanggar Kegiatan Belajar (SKB) merupakan usaha-usaha yang dilakukan oleh pimpinan selaku supervisor untuk mengkoordinir dan membimbing secara kontinu perkembangan pamong belajar, baik secara individu maupun secara kelompok agar mereka lebih memahami dan menyadari peran dan tanggung jawab sebagai tenaga pendidik dalam rangka kemajuan suatu lembaga pendidikan. Dengan demikian, maka memungkinkan para pamong belajar untuk dapat melaksanakan tugas dengan penuh ketaatan dan tanggung jawab baik secara individu maupun secara bersama-sama untuk melaksanakan apa yang menjadi keputusan institusi dan berusaha dengan memenuhi komitmen untuk mencapai hasil yang optimal.

Untuk mendapatkan hasil yang optimal, kegiatan supervisi dilakukan secara terprogram dan kontinu. Hal ini akan memungkinkan terciptanya pe- 
luang bagi pamong belajar untuk mengkomunikasikan setiap permasalahan yang dihadapi dan secepatnya mendapatkan pemecahannya. Di samping itu, kontinuitas supervisi akan membangkitkan kinerja pamong belajar karena selalu merasa ada bantuan dan kontrol dari pimpinan. Dengan demikian, dapat dikatakan bahwa semakin intensif kegiatan supervisi, maka akan semakin tinggi kinerja pamong belajar.

Berdasarkan kerangka pikir di atas, hipotesis penelitan dapat dirumuskan seperti berikut.

- Terdapat hubungan positif dan signifikan antara pengorganisasian program dengan kinerja pamong belajar.

- Terdapat hubungan positif dan signifikan antara motivasi kerja dengan kinerja pamong belajar.

- Terdapat hubungan positif dan signifikan antara intensitas supervisi dengan kinerja pamong belajar.

- Terdapat hubungan positif dan signifikan antara pengorganisasian program, motivasi kerja, dan intensitas supervisi dengan kinerja pamong belajar.

Dalam menguji hipotesis, peneliti menggunakan analisis statistik deskriptif, korelasi, dan regresi dengan menggunakan bantuan program SPSS for Window. Pengujian hipotesis menggunakan korelasional, yaitu dengan melihat nilai signifikansi yang diperoleh tiap variable, kemudian dibandingkan dengan nilai $\alpha$ (0.05). Jika Sig $\leq 0.05$, maka Ho ditolak.

\section{HASIL}

Untuk mengetahui apakah data yang dianalisis dengan menggunakan statistik parametrik memenuhi asumsi bahwa data harus berdistribusi normal dan linear, maka perlu diadakan pengujian. Uji normalitas data penelitian dengan menggunakan data galat taksiran berdasarkan model regresi yang terbentuk dengan menggunakan uji Liliefors. Kriteria uji normalitas adalah $\mathrm{H}_{0}$ : Lhit $<$ Ltab $=$ normal. $\mathrm{H}_{1}$ : Lhit $>$ Ltab $=$ tidak normal.

Dari hasil perhitungan dapat diketahui bahwa $\mathrm{F}$ (zi)-S(zi)l yang disimbolkan dengan Lhit untuk sebaran galat taksiran berdasarkan model regresi, lebih kecil dari nilai kritis. Hasil analisis: (1) $\mathrm{X} 1$ dengan $\mathrm{N}=63$, Lhit $=0,128<\mathrm{L}$ tab = 0,129; (2) X2 dengan $N=63$, Lhit $=$ $0,115<$ Ltab $=0,129$; (3) $\mathrm{X} 3$ dengan $\mathrm{N}=$ 63, Lhit $=0,122<$ Ltab $=0,129$. Berdasarkan hasil analisis di atas, maka tiga variabel bebas termasuk dalam kategori normal.

Sebelum pengujian hipotesis korelasional, perlu diketahui besarnya koefisien korelasi antara variabel bebas sebagai dasar untuk memeriksa masalah multikolinearitas. Edward (1979) menjelaskan bahwa koefisien korelasi antarvariabel bebas diharapkan tidak mencapai 0,80, bila koefisien korelasi antarvariabel bebas $>0,80$ akan terjadi multikolonearitas. Multikolinearitas dapat menimbulkan turunnya indeks korelasi parsial bila ada variabel bebas lain yang dikontrol.

Hasil perhitungan korelasi sederhana antarvariabel, yaitu variabel pengorganisasian program (X1), motivasi kerja (X2), intensitas supervisi (X3) dengan kinerja pamong belajar $(\mathrm{Y})$ disajikan pada Tabel 3 berikut. 
Tabel 3. Matriks Korelasi Sederhana antarvariabel Penelitian

\begin{tabular}{ccccc}
\hline Variabel & $\mathrm{X} 1$ & $\mathrm{X} 2$ & $\mathrm{X} 3$ & $\mathrm{Y}$ \\
\hline $\mathrm{X} 1$ & & 0,651 & 0,509 & 0,843 \\
X2 & & & 0,589 & 0,766 \\
X3 & & & & 0,675 \\
\hline
\end{tabular}

Masing-masing koefisien korelasi antara variabel bebas (X1, X2, dan X3) terhadap variabel terikat $(\mathrm{Y})$ adalah signifikan pada taraf signifikansi 5\%. Matriks korelasi tersebut di atas menunjukkan bahwa tidak terjadi multikolinearitas. Hal itu dikarenakan tidak terjadi korelasi yang tinggi antara variabel bebas.

Tabel 4. Hasil Penelitian No Hipotesis Penelitian Korelasi (r) pada Taraf

1. Terdapat hubungan positif dan signifkan antara peng-

Signifikan 5\% organisasian program dengan kinerja pamong belajar

2. Terdapat hubungan positif dan signifkan antara motivasi kerja dengan kinerja pamong belajar

3. Terdapat hubungan positif dan signifkan antara intensitas supervisi dengan kinerja pamong belajar

4. Terdapat hubungan positif dan signifkan antara pengorganisasian program, motivasi kerja, dan intensitas supervisi dengan kinerja pamong belajar.

\section{PEMBAHASAN}

Berpijak pada hasil analisis data sebagaimana yang telah diuraikan di atas, ada beberapa hal yang perlu pembahasan.
Hubungan antara Pengorganisasian Program dengan Kinerja Pamong Belajar

Pengorganisasian program sebagai kegiatan menyusun dan membentuk hubungan-hubungan kerja individu sehingga terwujud kesatuan usaha untuk mencapai tujuan yang telah ditetapkan merupakan salah satu fungsi manajemen yang harus dikuasai oleh setiap pamong belajar.

Seorang pamong belajar yang memiliki kemampuan profesional dalam bentuk pengetahuan, sikap dan keterampilan mengorganisasikan SKB akan memungkinkan baginya untuk dapat mengaktualisasikan melalui tindakan nyata atau penampilan dalam perencanaan, pelaksanaan sampai pada kegiatan evaluasi program pendidikan yang intensif dan efektif. Pamong belajar tidak dapat mengaktualisasikan diri melalui penampulan kerja yang baik, apabila ia tidak memiliki kemampuan profesional tentang cara mengorganisasikan program pendidikan secara efektif. Hal ini menimplikasikan bahwa kemampuan menorganisasikan program pendidikan merupakan kemutlakan bagi setiap pamiong belajar apabila ingin memiliki kinerja yang tinggi.

Hal lain yang dapat dijelaskan yaitu hasilpenelitian diperoleh variabel pengorganisasian program lebih besar hubungannya dengan kinerja pamong belajar dibandingkan dengan variabel motivasikerja dan intensitas supervisi pimpinan. Hasil ini dapat dijelaskan bahwa kemampuan mengorganisasikan program merupakan modal dasar bagi pamong belajar untuk membuat perencanaan sampai pada pelaksanaan pro- 
gram. Dengan kemampuan mengorganisasi program, pamong belajar akan memiliki rasa percaya diri (self concept) dalam menyelenggarakan tugas pembelajaran pada SKB.

Hasil penelitian mendukung kajian teori yang telah dibahas pada bab sebelumnya. Salah satu teori yang didukung oleh hasil penelitian ini ialah yang dikemukakan Terry (Kambey, 2006) bahwa pengorganisasian merupakan kegiatan dasar manajemen. Pengorganisasian program dilakukan dalam rangka untuk mencapai tujuan program yang ditetapkan. Dengan pengorganisasian program, semua sumber daya yang tersedia dapat berperan sesuai tugas dan fungsi yang dilimpahkan. Pada kondisi/situasi seperti ini, kinerja pamong belajar akan meningkat.

\section{Hubungan antara Motivasi Kerja de- ngan Kinerja Pamong Belajar}

Motivasi merupakan daya atau kekuatan yang menggerakkan seseorang untuk melakukan sesuatu sebagaimana yang ia dambakan. Motivasi erat kaitannya dengan kebutuhan, dalam arti bahwa seseorang tergerak melakukan sesuatu karena ingin memenuhi sesuatu kebutuhan. Motivasi adalah suatu kekuatan baik dari dalam maupun dari luar yang membuat seseorang untuk bertindak.

Hasil penelitian menunjukkan bahwa terdapat hubungan positif antara motivasi kerja dengan kinerja pamong belajar. Hasil ini mengisyaratkan betapa penting motivasi kerja ditanamkan kepada pamong belajar agar mereka memiliki kinerja yang tinggi dalam menyelenggarakan program pembelajaran pada SKB. Daya yang dimiliki oleh pamong belajar akan diaktualisasikan dalam bentuk aksi atau tindakan yang menghasilkan sesuatu dalam bentuk kinerja yang dapat diamati dan dirasakan. Tanpa adanya motivasi kerja yang tinggi, tidak mungkin pamong belajar akan melakukan pekerjaan secara optimal.

Hasil penelitian yang menyatakan bahwa terdapat hubungan positif antara motivasi kerja dengan kinerja pamong belajar mendukung kajian teori yang telah dibahas sebelumnya. Salah satu kajian teori yang didukung dalam penelitian ini adalah yang dikemukakan oleh MC. Donald (1988) bahwa motivasi dimulai dengan suatu perubahan tenaga dalam diri seseorang. Motivasi dilandasi oleh dorongan afektif, dan motivasi ditandai oleh reaksi-reaksi untuk mencapai tujuan. Ketiga komponen ini merupakan faktor pemicu kinerja pamong belajar. Semakin tinggi perubahan tenaga dalam diri seseorang untuk mencapai tujuan, akan semakin tinggi kineja pamong belajar untuk melaksanakan tugas yang dipercayakan.

\section{Hubungan antara Intensitas Supervisi dengan Kinerja Pamong Belajar}

Supervisi dalam SKB merupakan usaha yang dilakukan oleh pimpinan selaku supervisor untuk mengkoordinir dan membimbing secara kontinu perkembangan pamong belajar, baik secara individu maupun secara kolektif agar mereka lebih memahami dan menyadari peran dan tanggung jawab sebagai enaga pendidik dalam rangka kemajuan lembaga pendidikan. 
Hasil penelitian menunjukkan bahwa terdapat hubungan positif antara supervisi pimpinan dengan kinerja pamong belajar. Walaupun hasilnya tidak sama dengan variabel pengorganisasian program dan motivasi kerja, akan tetapi variabel ini akan tetap diperhatikan dalam rangka meningkatkan kinerja pamong belajar.

Untuk mendapatkan hasil yang optimal, kegiatan supervisi dilakukan secara terprogram dan kontinu. Hal ini akan memungkinkan terciptanya peluang bagi pamong belajar untuk mengkomunikasikan setiap permasalahan yang dihadapi dan secepatnya mendapat pemecahan. Di samping itu, kontinuitas supervisi akan membangkitkan kinerja pamong belajar karena selalu merasa ada bantuan dan kontrol dari pimpinan.

Hasil penelitian ini mendukung teori Blumberg (1980) yang menjelaskan bahwa adanya supervisi dapat menumbuhkan iklim yang kondusif bagi perbaikan proses dan hasil pekerjaan seseorang. Dengan adanya upaya perbaikan proses dan hasil melalui kegiatan supervsi, akan memicu kinerja pamong belajar untuk melakukan tugas sebagaimana yang dipercayakan oleh lembaga.

Hubungan antara Pengorganisasian Program, Motivasi Kerja, dan Intensitas Supervisi dengan Kinerja Pamong Belajar

Dalam penyelenggaraan program di $\mathrm{SKB}$, pengorganisasian program dan motivasi kerja adalah komponen yang dimiliki oleh pamong belajar, sedangkan intensitas supervisi adalah kom- ponen yang dimiliki pimpinan lembaga. Hasil penelitian menunjukkan bahwa terdapat hubungan positif antara pengorganisasian program, motivasi kerja, dan intensitas supervisi dengan kinerja pamong belajar. Walaupun terdapat perbedaan hasil dari ketiga variabel dalam pengujian secara terpisah, akan tetapi dalam pengujian secara bersama-sama ternyata memiliki hubungan yang berarti.

Hal di atas telah memberikan isyarat bahwa pengorganisasian program, motivasi kerja, dan intensitas supervisi tidak boleh diabaikan dalam kaitannya dengan peningkatan kinerja pamong belajar pada kegiatan SKB. Artinya, setiap kegiatan yang berkaitan dengan peningkatan kinerja pamong belajar harus ada upaya pengorganisasian program, motivasi kerja, dan intensitas supervisi secara terpadu atau bersama-sama.

\section{PENUTUP}

Dari hasil penelitian dan pembahasan seperti yang telah diuraikan di atas, dapat ditarik kesimpulan sebagai berikut.

- pengorganisasian program pendidikan pada SKB mempunyai hubungan positif dan signifkan dengan kinerja pamong belajar. Hal ini menunjukkan bahwa jika pamong belajar memiliki kemampuan mengorganisasikan program pendidikan, maka kinerjanya juga akan meningkat. Sebaliknya, jika pamong belajar kurang memiliki kemampuan dalam pengelolaan program pendidikan, kinerja mereka akan menurun.

- Motivasi kerja pamong belajar mempunyai hubungan positif dan signi- 
fikan dengan kinerja. Hal ini menunjukkan bahwa jika motivasi kerja pamong belajar meningkat, kinerja akan meningkat. Sebaliknya, jika motivasi kerja pamong belajar menurun, kinerja mereka akan menurun.

- Intensitas supervsi oleh pimpinan mempunyai hubungan positif dan signifikan dengan kinerja pamong belajar. Hal ini menunjukkan bahwa semakin intensif pimpinan SKB melakukan supervisi, maka semakin meningkat kinerja pamong belajar. Sebaliknya, jika pimpinan kurang intensif dalam kegiatan supervisi, kinerja pamong belajar juga akan menurun.

- Pengorganisasian program dan motivasi kerja pamong belajar serta intensitas supervisi pimpinan SKB secara bersama-sama mempunyai hubungan positif dan signifikan dengan kinerja pamong belajar. Hal ini menunjukkan bahwa pengorganisasian program dan motivasi kerja pamong belajar serta intensitas supervisi pimpinan SKB secara nyata dapat menentukan dan memberikan kontribusi yang signifikan erhadap kinerja pamong belajar. Dalam arti, apabila pengorganisasian program dan motivasi kerja serta intensitas supervise secara bersama-sama ditingkatkan, maka kinerja pamong belajar akan meningkat. Sebaliknya, apabila pengorganisasian program, motivasi kerja, dan intensitas supervisi menurun, kinerja pamong belajar juga akan menurun.

Kesimpulan seperti yang dikemukakan di atas menunjukkan bahwa terdapat hubungan yang signifikan antara pengorganisasian program dan moti- vasi kerja pamong belajar serta intensitas supervisi pimpinan SKB. Kontribusi pengorganisasian program dan motivasi kerja pamong belajar serta intensitas supervisi pimpinan SKB sebesar $81 \%$ dalam meningkatkan kinerja pamong belajar sangat besar artinya. Dikatakan demikian karena masih terdapat faktor lain yang juga ikut berperan dalam perubahan kinerja pamong belajar yang tidak dilakukan dalam penelitian ini. Oleh karena itu, dapat dikatakan bahwa pengorganisasian program dan motivasi kerja pamong belajar serta intensitas supervisi pimpinan memegang peranan penting dalam meningkatkan kinerja pamong belajar.

\section{SARAN}

Berpijak pada kesimpulan dan implikasi hasil penelitian di atas, dapat dikemukakan beberapa saran seperti berikut.

- Pihak Depdiknas, secara khusus Direktorat Pendidik dan Tenaga Kependikakan Non-Formal, Direktorat Jenderal Pengelolaan Mutu Pendidik, dan Tenaga Kependidikan hendaknya secara kontinu meningkatkan pelaksanaan program yang dapat menunjang peningkatan kinerja para pamong belajar dalam bentuk pelatihan dengan tujuan memberikan kemampuan mengorganisasikan program pendidikan dan meningkatkan motivasi kerja. Di samping itu, pelatihan bagi pimpinan dengan tujuan mengembangkan kemampuan profesional untuk melakukan supervisi.

- Lembaga pendidikan yang menghasilkan tenaga kependidikan nonformal diharapkan mampu menghasil- 
kan tenaga-tenaga profesional yang memiliki kemampuan mengorganisasikan program pendidikan dan memiliki motivasi kerja yang tinggi dalam mengemban tugas dan tanggung jawab sebagai pamong belajar. Di samping itu, lembaga tersebut seharusnya mampu menghasilkan lulusan yang profesional dalam melakukan supervisi program-program pendidikan nonformal.

- Hendaknya pimpinan SKB dapat menciptakan iklim lembaga yang memungkinkan para pamong belajar memiliki kemandirian dalam mengembangkan diri secara individu atau kelompok untuk mendapatkan kemampuan profesionaldalam mengorganisasikan program pendidikan serta saling membangkitkan motivasi kerja.

- Hendaknya pimpinan SKB secaa kontinu melakukan kegiatan supervisi dan selalu berusaha mencari dan mengembangkan strategi supervisi yang dapat meningkatkan kinerja para pamong belajar.

- Hendaknya dilakukan penelitian lanjutan untuk mengetahui faktor-faktor yang dapat meningkatkan kemampuan pengorganisasian program, motivasi kerja dan intensitas supervisi.

\section{UCAPAN TERIMA KASIH}

Terima kasih disampaikan kepada pimpinan SKB di Kabupaten/Kota Propinsi Sulawesi Utara yang telah memberikan kesempatan pada peneliti untukmengadakan penelitian di SKB yang Bapak/bu pimpin. Terima kasih juga disampaikan kepada Pengurus dan Redaktur Jurnal Cakrawala Pendidikan yang telah memberikan kesempatan kepada penulis untuk mengisi hasil penelitian di jurnal tersebut.

\section{DAFTAR PUSTAKA}

Baedhowi. 2007. Manajemen Sumber Daya Manusia. Semarang: Pelita Insani.

Blumberg, Arthur. 1980. Supervisors And Teacher: A Private Cold War. Berkeley California: Mc. Cutchan Publishing Co.

Connor, P.E., Haiman, T., and Scott, W. G. 1974. Dimensions in Modern Manajemen. Boston: Houghton Miffin Company.

Departemen Pendidikan Nasional. 1999. Keputusan Menteri Negara Koordinator Bidang Pengawasan Pembangunan Aparatur Negara. Jakarta.

Departemen Pendidikan Nasional. 2009. Peraturan Pemerintah Nomor 74 tentang Guru. Jakarta

Flippo, E.B., and Musionger, G.M. 1975. Manajemen. Boston: Allyn and Bacon, Inc.

Kambey, D.C. 2006. Landasan Teori Administrasi/Manajemen.Manado:Yayasan Tri Ganesha Nusantara.

Longenecher, J.G., 1973. Principles of Manajemen and Organizational Behavior. Colombus, Ohio: Charle E. Merril Publishing Company.

Mc Donald, Fredrick J. 1988. Educational Psychology. San Fransisco: Wadsworth Publishing Company. 
Pidarta, Made. 1988. Manajemen Pendidikan Indonesia. Jakarta: Bumi Aksara.

Sedarmayati. 1996. Tata Kerja dan Produktivitas Kerja. Bandung: Mandar Maja.

Simamora, H. 2004. Manajemen Sumber Daya Manusia. Yogyakarta: STIE YPKN.

Sukmadinata, Nana Syaodih. 2009. Metode Penelitian Pendidikan. Bandung: Remaja Rosdakarya.
Suprihanto. 1998. Penilaian Kinerja dan Pengembangan Tenaga Kerja. Yogyakarta:BPFE.

Tuckman, Bruce. 1972. Conducting Educational Research. New York: Harcourt Jovannovich.

Whitmore, John. 1997. Seni Mengarahkan untuk Mendongkrak Kinerja. (Terjemahan Y. Dwi Helly Purnomo. Jakarta: Gramedia Pustaka. 